\title{
Moral Teaching in the Age of Digital Economy: A Model for Elementary School Character Education for Sustainable Development
}

\author{
Badawi $^{1}$, Sri Nurhayati ${ }^{2}$, Ahmad Wahyu Hidayat ${ }^{3}$, Muhammad Ilham Syarif ${ }^{4}$, \\ Muhammad Iqbal Fasa ${ }^{5}$ \\ \{badawi@umko.ac.id ${ }^{1}$,srinurhayati@ikipsiliwangi.ac.id², ahmadwahyuhidayat95@gmail.com³ \\ Universitas Muhammadiyah Kotabumi, Tanjung Harapan Kotabumi ${ }^{1}$, Institut Keguruan dan Ilmu \\ Pendidikan Siliwangi, Town Place Baros Cimahi ${ }^{2}$, Universitas Islam Negeri Sunan Kalijaga Yogyakarta, \\ Muba Sumsel $^{3}$
}

\begin{abstract}
This paper aims to study the implementation of moral teaching in this age of the digital economy as a character education model at the elementary school level as an effort toward sustainable development. The research used a case study method, in a total of 10 elementary school teachers in SD Sukarno Hatta Kotabumi were interviewed, participated in the focused group discussion, and observed. The research findings are the teachers' practice of moral teaching in the digital economy era using straightforward activities and emphasized more in the thematic entrepreneurship lesson. The essential characters to be practiced by the students in the context of sustainable development consist of mindfulness, curiosity, courage, resilience, ethics, and leadership.
\end{abstract}

Keywords: Moral Teaching, Character Education, Sustainable Development

\section{Introduction}

The development of digital technology today makes millennial generations since the young age of elementary education already able to transact digital goods and services, so they need to be morally well educated in order to form a character full of integrity in doing digital economic practice and prepare them to be the best human resources ready to create sustainable development in the digital economic era.

The implementation of character education in elementary schools has not met expectations [1]. The main problem is that many elementary schools in Indonesia have not yet made the values of character in the nearest elementary school environment a core value in character education. Besides, core values or targets have not been included in the vision, mission, and goals of education in elementary schools. Much researches have previously been conducted on character building [2] [3], on character impact on school climate [4], and strategies of building character [5]. These studies have discussed the strategy and program of character building and its influence on the school's climate. The character learning model has also been developed by Amran, Jasin, Satriawan, \& Perkasa. This model has the syntax of the post, discussing, analyzing, communicating, and effectively [6].

Nevertheless, the researcher's knowledge, there has been no research focused on describing how character education in the digital economic era is for elementary school children. Thus, this paper seeks to fill the void. The methods offered in this research seek to understand the topic in-depth, which is a sophisticated phenomenon for researchers and professionals (teachers). This article aims to provide a conceptual framework derived from the Empiric 
findings in the field of moral learning for elementary school children in the digital economic era.

The structure of the research discussion includes a discussion on the extent to which the study of moral teaching for elementary school students has been conducted to date, the contribution of this research is to discuss findings on moral teaching in the era of digital economy derived from the data in the field, subsequently closed with the conceptual framework of character education model formulated from data findings in the field.

\section{Literature Review}

\subsection{Digital Economy}

The digital economy is seen as one of the economic activities involving technology that can be carried out on the World Wide Web (WWW) and the internet. Richard Barbrook [7] defines that the digital economy is characterized by the emergence of new technologies related to computer networks and new types of workers with digital competence. Furthermore, according to Barbrook Digital Exnomi is a mixed economy of several elements, namely public elements, elements that are moving by the market, and economic elements of the prize. According to Bazzoun [8] noting that the challenges in the industrial revolution era 4.0 were the implementation of technology-based, hyper-connected, supercomputing, and smart product livelihoods. This positively will affect the human economic system. Digital economic development results in more extensive employment opportunities[9].

\subsection{Character Education}

Character education is the attitude of students to describe the teaching of children and adults in a way that will help them develop as diverse as moral, civic, ethical, behaving, not bluffing, healthy, critical, prosperous, traditional, obedient, or acceptable social [10]. In this term, current and past concepts include social and emotional learning, moral reasoning and cognitive development, life skills education, health education, violence prevention, critical thinking, ethical reasoning, and conflict resolution and mediation. Lickona [11] said that that character could be seen in three elements: moral knowledge, moral feelings, and moral actions. Based on these three elements, a person is considered to have good character if they know about good things (knowing morals), have an interest in good things (moral feelings), and do right actions (moral actions).

\subsection{Sustainable Development}

The term sustainable development has many different meanings. Some prioritize sustainable economic growth, and some prioritize sustainable human development [12]. Fiend and Tilbury [13] stated that the first group emphasized technological and economic tools rather than individual, group, and industry activities to the path to sustainable development. In contrast, the second group focuses more on socials justice and ecological boundaries. Dasgupta [14] defines sustainable development as an economic program of the average current generation, and future welfare will not diminish if combined.

Education is also part of sustainable development. Summers, Childs, and Corney [15] stating that sustainable development education (ESD) is an effort to develop the knowledge, values, and skills of one to participate in making decisions in various ways both individually 
and collectively in the global and local contexts, which will improve the quality of life now and without damaging the life order of Imasa ahead. This is in line with the thought of Burmeister et al. [16], which emphasizes that the primary focus of ESD is to prepare the younger generation to become responsible citizens in the future. Furthermore, Tilbury [17] also identifies critical processes of ESD learning, which encourages students to think critically reflective, clarify values, visualize a more positive future, think systematically, be able to conduct applied learning and be able to incorporate tradition and innovation

\subsection{Moral values}

Moral Values are Values related to good and bad deeds that guide human life in general [18]. Moral value is one aspect that must be understood and implemented in people's lives [19]. However, in the era of the industrial revolution 4.0, the implementation suffered a setback because of the influence of technological developments[20]. This has become welcome in the field of education to maintain moral values and form human resources that can adapt to the conditions of the times. Research Bialik, Bogan, Fadel, \& Horvathova [21] identify six character qualities:

\begin{tabular}{|c|c|}
\hline Top Qualities & Associated Qualities and Concepts (non-exhaustive) \\
\hline Mindfulness & $\begin{array}{l}\text { Wisdom, self-awareness, self-management self-actualization, observation, } \\
\text { reflection, consciousness, compassion, gratitude, empathy, caring, growth, vision, insight, } \\
\text { equanimity, happiness, presence, authenticity, listening, sharing, interconnectedness, } \\
\text { interdependence, oneness, acceptance, beauty, sensibility, patience, tranquility, balance, } \\
\text { spirituality, existentiality, social awareness, cross-cultural awareness, etc. }\end{array}$ \\
\hline Curiosity & $\begin{array}{l}\text { Open-mindedness, exploration, passion, self-direction, motivation, initiative, innovation, } \\
\text { enthusiasm, wonder, appreciation, spontaneity etc. }\end{array}$ \\
\hline Courage & $\begin{array}{l}\text { Bravery, determination, fortitude, confidence, risk taking, persistence, toughness, zest, optimism, } \\
\text { inspiration, energy, vigor, zeal, dieerfulness, humor etc. }\end{array}$ \\
\hline Resilience & $\begin{array}{l}\text { Perseverance, grit, tenacity, resourcefulness, spunk, self-discipline, effort, diligence, } \\
\text { commitment, self-control, self-esteem, confidence, stability, adaptability, dealing with ambiguity. } \\
\text { lexibility, feedback, etc. }\end{array}$ \\
\hline Ethics & $\begin{array}{l}\text { Benevolence, humaneness, integrity, respect, justice, equity, fairness, kindness, altruism, } \\
\text { inclusiveness, tolerance, acceptance, loyalty, honesty, truthfulness, authenticity. genuineness, } \\
\text { trustworthiness, decency, consideration, forgiveness, virtue, love, helpfulness, generosity, } \\
\text { darity, devotion, belonging, civic-mindedness, citizenship, equality, etc. }\end{array}$ \\
\hline Leadership & $\begin{array}{l}\text { Responsibility, abnegation, accountability, dependability, reliability, conscientiousness, } \\
\text { selflessness, humbleness, modes ty, relationship skills, self-reflection, inspiration, organization, } \\
\text { delegation, mentorship, commitment, heroism, charisma,followership, engagement, leading by } \\
\text { example, goal-orientation, focus, resuits orientation, precision, execution, efficiency, negotiation, } \\
\text { consistency, sociatization, social intelligence, diversity, decorum, etc. }\end{array}$ \\
\hline
\end{tabular}

Fig.1. moral values

Based on the table above, there are indicators in measuring moral and character students. This can be used as a solution by the teacher in teaching moral values to students.

\section{Method}

This research uses the case study method. This research is focused on the conditions of moral learning related to the digital economy in Sukarno Hatta Elementary School Kotabumi Lampung Utara. The purposive sampling method is used to determine the subject of research: ten teachers (five grade six teachers and five fifth grade teachers) who provide moral instruction in entrepreneurial subjects in elementary school. Data collection is done by 
compiling a semi-guided interview guide and reviewing related literature. The data was suggested from interviews with teachers from the odd semester of the 2019-2020 school year, where subjects with an entrepreneurial theme took place. After the data was accumulated until June 2019, researchers then analyzed the data through several stages. First, outline and select the required data in the study. Secondly, data is presented in a narrative form to illustrate the moral teaching process, and then researchers analyze the data. Third, researchers conclude from the analysis that will be the result of the research done.

\section{Result And Discussion}

\subsection{Moral Teaching in the age of the digital era}

To find out moral teaching for elementary students in the context of the digital economy, it can be seen in entrepreneurial lesson. The majority of teachers teach by giving examples and direct practice about entrepreneurship digitally. One teacher explains the good teaching practice that teachers have done in entrepreneurial learning instruction, "First, as educators, we must set an example. Then, students must understand why morals must still be built in all aspects. After that, we determine what moral values must be in entrepreneurship. In entrepreneurship, it is necessary to have ethics so that the marketing strategy can continue and the goals are achieved. Students need to know that entrepreneurship is not only related to transactions, but there is a value of hospitality that is formed. ". Some teachers also added that sampling could be performed by displaying images, videos, and real stories or stories. These teachers state the reasons for providing examples and direct practice in teaching that students can immediately feel, understand and conduct entrepreneurial learning, and apply the moral values that have been given.

If seen, moral learning does not have a specialized curriculum in primary schools. Moral learning is usually integrated into every subject at school. According to Suparno, Paul, Moerti, Titisari, and Kartono[22] that this learning model is called an integrated model, where teachers can choose several character values to be included in the subject matter. In this case, the teacher plays an essential role in teaching moral in school. According to Washington, Clark \& Dixon[23], The teacher is responsible for educating character values to students.

\subsection{Important moral values toward sustainable development}

The majority of teachers have the view that good morals are related to sustainable development. They assume that sustainable development will be realized if humans in it have good morals. One of the teachers argued, "Sustainable development is a product of an advanced nation in which there are human resources who have a mindset and good morals." Furthermore, related to moral values that need to be given to make students as the leading players in sustainable development in the future, all teachers state that the value of honesty is a moral value that must be given to students. Furthermore, others add other moral values, such as responsibility, discipline, and high-competitiveness. Based on research by Bialik, Bogdan, Fadel \& Horvathova [21], there are six essential character qualities in 21st-century education, namely mindfulness, curiosity, courage, toughness, ethics, and leadership. 


\subsection{A Model of Character Education for Sustainable Development}

Moral teaching is needed to be able to shape the character of students. Lickons[11] revealed that character could be seen from moral knowledge, moral feelings, and moral actions. Based on the results of an analysis of moral teaching practices by teachers in entrepreneurial learning, a character education model for sustainable development in elementary schools was found. The following steps are for character education in the digital economy:

a. Explain various experiences in everyday life in interacting digital economy.

b. Identifying the moral values of the experience.

c. Explain the effects of moral values on the future of children, the future of the environment, and the future of civilization.

d. Provide exercises that can provide opportunities for students to express their ideas and behavior.

Based on research by Farrington et al.[24] stated that student capacities other than knowledge and skills were essential indicators of achievement and proved to be more useful in the world of work. This shows that the character possessed by someone is more useful in future work.

\section{Conclusions}

The character education Model in this paper provides a perspective to develop moral learning in the context of the digital economy for sustainable development. The character education Model presented is by explaining moral values and giving students a direct experience regarding digital economic practice. Explaining the character education model in digital economic practice like this is certainly not enough for teachers to educate morals to realize sustainable development. Teachers still need the education to improve their competence in teaching morals. In addition, facilitation in primary schools has also had to support improving entrepreneurial literacy in the context of the digital economy. This can be supported by implementing an elementary school curriculum on complete and comprehensive character education because of human resource needs when the era of the 4.0 industry's revolution should be intelligent and capable of developing a digitized economy. Further studies are expected to discuss the effectiveness of this character education implementation model.

\section{References}

[1] W. Althof and M. W. Berkowitz, "Moral education and character education: Their relationship and roles in citizenship education," J. Moral Educ., vol. 35, no. 4, pp. 495-518, 2006.

[2] C. L. Glenn, "Character-building and freedom in education," Eur. J. Educ. Law Policy, vol. 2, no. 2 , pp. $125-144,1998$.

[3] L. Silanoi, "The development of teaching pattern for promoting the building up of character education based on sufficiency economy philosophy in Thailand," Procedia-Social Behav. Sci., vol. 69, pp. 1812-1816, 2012.

[4] R. White and N. Warfa, "Building schools of character: A case-study investigation of character education's impact on school climate, pupil behavior, and curriculum delivery," J. Appl. Soc. 
Psychol., vol. 41, no. 1, pp. 45-60, 2011.

[5] A. Lumpkin, "Building character through sports," Strategies, vol. 24, no. 6, pp. 13-15, 2011

[6] A. Amran, I. Jasin, M. Satriawan, and M. Perkasa, "Developing Education for Sustainable Development-Oriented-Character Learning Model for Indonesian Golden Generation," Asian Soc. Sci., vol. 15, p. 87, Nov. 2019.

[7] R. Barbrook, "The digital economy," Nettime. org, 1997.

[8] M. Bazzoun, “The Digital Economy,” Int. J. Soc. Sci. Econ. Invent., 2019.

[9] V. Ivanova, A. Poltarykhin, A. Szromnik, and O. Anichkina, "Economic policy for country's digitalization: A case study," Entrep. Sustain. Issues, 2019.

[10] J. Suissa, "Character education and the disappearance of the political," Ethics Educ., 2015.

[11] T. Lickona, "My thought about character," Itaca London Cornell Univ. Press, 2003.

[12] A. Dobson, "Environment sustainabilities: An analysis and a typology," Env. Polit., vol. 5, no. 3, pp. 401-428, 1996.

[13] J. Fien and D. Tilbury, "The global challenge of sustainability," Educ. Sustain. Responding to Glob. Chall., vol. 1, 2002.

[14] P. Dasgupta, "Measuring Sustainable Development: Theory and Application. Asian Development Review, Vol. 24 (1), pp. 1-10," 2007.

[15] M. Summers, A. Childs, and G. Corney, "Education for sustainable development in initial teacher training: Issues for interdisciplinary collaboration,” Environ. Educ. Res., vol. 11, no. 5, pp. 623-647, 2005.

[16] M. Burmeister and I. Eilks, "An example of learning about plastics and their evaluation as a contribution to Education for Sustainable Development in secondary school chemistry teaching," Chem. Educ. Res. Pract., vol. 13, no. 2, pp. 93-102, 2012.

[17] D. Tilbury, "Education for sustainable development: An expert review of processes and learning (p 132)," Paris UNESCO. http//unEfSoc. unesco. org/images/0019/001914/191442e. pdf. Last Accessed January, vol. 24, p. 2016, 2011.

[18] E. F. F. Khomaeny and G. N. Mukhlis, "Pendidikan karakter untuk anak usia dini menurut Q.S. Lukman: 13-19," Pedogagi J. Anak Usia Dini dan Pendidik. Anak Usia Dini, 2017.

[19] K. St. Komariah, "Model Pendidikan Nilai Moral Bagi Para Remaja Menurut Perspektif Islam," J. Pendidik. Agama Islam., 2019.

[20] M. Fineman, "Book Review: Family Values: Between Neoliberalism and the New Social Conservatism," Soc. Leg. Stud., 2017.

[21] M. Bialik, M. Bogan, C. Fadel, and M. Horvathova, "Character education for the 21st century: What should students learn," Boston, Massachusetts Cent. Curric. Redesign, 2015.

[22] F. Rokhman, M. Hum, A. Syaifudin, and Yuliati, "Character Education for Golden Generation 2045 (National Character Building for Indonesian Golden Years)," Procedia - Soc. Behav. Sci., vol. 141, pp. 1161-1165, Aug. 2014.

[23] E. Y. Washington, A. Clark, and A. L. Dixon, “ "Everyone In School Should Be Involved”: Preservice Counselors' Perceptions of Democracy and the Connections Between Character Education and Democratic Citizenship Education," J. Character Educ., vol. 6, no. 2, p. 63, 2008.

[24] C. A. Farrington et al., Teaching Adolescents to Become Learners: The Role of Noncognitive Factors in Shaping School Performance--A Critical Literature Review. ERIC, 2012. 